\title{
ブランド・コミットメントと 購買行動との関係
}

\section{要約 (アブストラクト)}

本研究では、消費者の態度であるブランド・コミットメントによって実際の購買行動が説明できることを 確認した。コミットメントに関する先行研究の検討と複数カテゴリーのデータを用いた分析から、ブランド・ コミットメントの要素として感情的コミットメント、計算的コミットメント、陶酔的コミットメントの 3 つ を特定するとともに、ブランドの購買確率やバラエティ・シーキング行動、推奨行動との関係を明らかにした。 ブランド・コミットメントの各次元は消費者の行動に対して明確に異なった影響を及ぼしており、これらの 結果はブランドをマネジメントしていく上での有効な示唆を含んでいると考えられる。

キーワード

ブランド・コミットメント、感情的コミットメント、計算的コミットメント、陶酔的コミットメント、行 動的ロイヤルティ

\section{1. はじめに}

1980 年代からマーケティング領域全体に 浸透した関係性の志向は、ブランド研究やブ ランド・マネジメントの領域においても「ブ ランド一消費者」の関係を対象とした形で存 在する。ブランドと消費者との関係を記述す る代表的な概念としては、1950年代に登場 し一大テーマとなった「ブランド・ロイヤル ティ」や、リレーションシップ・マーケティ ングの議論以降に頻繁に取り上げられるよ うになった「ブランド・コミットメント」が ある。これらの概念はいずれも消費者による 特定ブランドの偏った選択や反復購買を説 明する中核的な変数と言える。とりわけ近 年においては、態度概念としてのブランド 。 コミットメントがよく用いられており、そ
の高低やタイプによって消費者の行動がど のように異なるかに関心が向けられている (たとえば Chaudhuri 2006; Raju, Unnava, and Montgomery 2009)。

元来コミットメントという概念は社会心 理学、組織論などの分野でそれぞれに研究 蓄積があり、マーケティングではそれら他 領域の定義や成果を援用することによって、 企業間関係、企業一消費者間関係を説明して きた。過去 20 年ほどの間に、マーケティン グ領域に打けるコミットメント概念の出現 頻度は明らかに増えており、非常に捉えに くい言葉でありながらもすでに市民権を得 ている。しかし、「援用」という形のために、 マーケティング領域でのコミットメント概 念やコンテクストについての十分な検討が 
行われてきたとは言えず、しばしば問題点と して指摘される（井上 2003、久保田・井上 2004、久保田 2006)。

本研究で取り扱う「ブランド・コミットメ ント」は文字通り特定のブランドに対するコ ミットメントを指し、消費者の態度として捉 えられる。態度は、行動意図や実際の行動の 前提となる変数ゆえに、消費者が当該ブラン ドに対して抱くコミットメントはブランド の未来やあり方を左右する重要な要素と言 える。本研究では、多様な意味合いや分類が 提示されているコミットメント概念を整理 した上で、ブランドに対する消費者のコミッ トメントの構造を特定するとともに、それら が実際の購買行動といかに関連しているの かを解明していきたい。

\section{2. ブランド・コミットメントに関する先 行研究の概観}

（1）ブランド・コミットメント概念

ブランド・コミットメントの概念打よびそ の関連研究を概観すると、2つの潮流を確認 できる。1つはブランド・コミットメントを 消費者関与の中の、特にブランドという対象 に向けられた関与として定義するものであ る。自我関与を源流とするこの流れに扎いて ブランド・コミットメントは、ある製品クラ ス内の特定ブランドに対する感情的ないし 心理的な結びつき (Lastovicka and Gardner 1977)、あるいは当該製品クラス内の唯一受 容可能な選択肢として消費者の心に強く根 ざしている程度（Traylor 1981）と捉えられ る。青木（2004） が指摘するように、関与 概念の研究においてブランド・コミットメン 卜に関する本格的な議論はほとんどなく、関 与の一部としてその言葉のみが提示された 状態で長年が経過してしまった感がある。い くつかの研究は製品関与とブランド・コミッ
トメントとの関連性を追究しているが、前者 が後者にプラスの影響を与えるという関係 を示唆する結果もあればそうでないものも あり、製品関与がブランド・コミットメン 卜を規定するという十分な証拠は得られて いない（Warrington and Shim 2000）。化粧 品カテゴリーを対象に製品関与とブランド • コミットメントの関係を再考した Coulter et al.(2003) は、「現在使用しているブランドを 非常に愛している」、「自分にとって当該ブ ランドがべストなのでこだわりをもってい る」、「当該ブランドを絶対的に支持してい る」の 3 つの質問項目からブランド・コミッ トメントの強さを探っている。概して対象特 定的関与としてのブランド・コミットメント は、強くて肯定的な感情やそれに裏付けられ た態度として捉えられている。

そしてブランド・コミットメント概念を取 り扱うもうひとつの潮流は、リレーション シップ・マーケティング研究の流れを汲むも のである。リレーションシップ・マーケティ ングは元来、産業財取引や流通取引といっ た $\mathrm{B}$ to $\mathrm{B}$ や B to C のサービス財分野を中心 に研究が行われてきた。その中でコミットメ ントは当事者間の有効なりレーションシッ プの成立、とりわけリレーションシップの継 続に大きな影響力を持つことが明らかにさ れており、中核的な概念として扱われてい る。比較的初期の研究では「交換パートナー との関係継続に関する暗黙的あるいは明示 的な誓約」（Dwyer et al. 1978） や、「価值 ある関係を維持したいという永続的な欲求」 (Moorman et al. 1992) などの定義がなされ ている。リレーションシップ・マーケティン グの文脈において、相手あるいは相手との関 係性に対するコミットメントは、相手を好ま しいと思う感情的な要素以外に、いかに当該 関係に自らが労力を投じているか、相手との 
関係によっていかに自分がメリットを得て いるかといった認知的な要素に左右される と考えられている。

こうしたリレーションシップ・コミットメ ントの流れを消費者ーブランド間のコンテ クストへ応用した研究では、先述した関与 としての強い思い入れに対して、クールな 側面も併せ持つ概念としてブランド・コミッ トメントが扱われている（たとえば Amine 1998 ; Fullerton 2005)。Fullerton(2005) は ブランドに対する消費者の満足とブランド . ロイヤルティの関係を媒介する変数として ブランド・コミットメントを用い、消費者が 特定のブランドへロイヤルになる合理化の プロセスを説明した。同研究では、感情的な コミットメントに加え、現在のブランドから 別のブランドにスイッチすることによる負 担やネガティブな影響を基盤とした存続的 コミットメント ${ }^{1}$ もブランド・コミットメン トとして包括的に捉えられている。コミット メント概念の多次元性については次項で改 めて議論したい。

最後に、近接概念として常に問題となるブ ランド・ロイヤルティとの関係について述べ ておこう。ブランド・コミットメント概念は ブランド・ロイヤルティ概念との対比で説明 されることが多い。ブランド・ロイヤルティ はブランドと消費者との関係性を記述する 概念としてマーケティング領域に打ける一 大テーマを築いた。同概念は 1950 年代に購 買データをもとにした研究から提唱された 背景があり、「行動的指標」としての色合い を強く持つ。これに対して、ブランド・コミッ トメントには見せかけのロイヤルティ（反 復購買という行動のみ) と真のロイヤルティ (ブランドに対する態度的な要素を伴う反復 購買）とを区別するという役割が期待されて きた（Bloemer and Kasper 1993 ; Dick and
Basu 1994）。そして現在までに行動的指標 はブランド・ロイヤルティ、態度的指標はブ ランド・コミットメントという分類が一般化 しつつある。

\section{（2）ブランド・コミットメントの次元}

前項で述べたように、ブランド・コミッ トメントの議論には異なった潮流があり、 概念の捉え方にも違いを確認することがで きる。Amine（1998）はリレーションシッ プ・コミットメントの多次元性に関する 議論を参考にして、ブランド・コミット メントを感情的コミットメント (affective commitment）と計算的コミットメント (calculative commitment) に分類している。 感情的コミットメントはブランドに対する 愛着（attachment）や情緒的要素を源泉とし、 計算的コミットメントは知覚リスクや競合 ブランド間の知覚差異といった認知的な評 価を源泉とする。彼はこれらについて経験的 な確認は行っていないが、ブランドに対する コミットメントの多次元的性質を指摘した 先駆的な研究と言える。

Fullerton（2005）はブランド・コミット メントを感情的コミットメントと存続的コ ミットメント (continuance commitment) の 2 次元に分け、Gap（アパレルブランド）と Tim Hortons (コーヒーチェーンブランド) を対象にその存在を確認するとともに、各コ ミットメントが消費者の異なった行動を導 くことを実証している。彼が提示した $2 つ$ の次元は組織コミットメントの分野で広く 受け入れられている Allen and Meyer(1990) の 3 分類、およびそれに基づいて行われた リレーションシップ・コミットメントの研究 知見から、組織あるいは取引相手にはコミッ トすべきであるという規範的コミットメン ト (normative commitment) を除いたもので 
ある。彼の研究に扎いて、感情的コミットメ ントは信頼や友好的な思いを源泉とするコ ミットメント、存続的コミットメントは代替 選択肢の少なさ、サイドベッド、スイッチン グ・コストを源泉とするコミットメントとし て捉えられている。

また Chaudhuri(2006) は態度的コミットメ ント（attitudinal commitment）と購買コミッ トメント (purchase commitment) という 2 次元でコミットメントを捉え、それぞれがブ ランドの成果（相対価格と市場シェア）に異 なった影響を及ぼすことを明らかにしてい る。彼の言う態度的コミットメントは感情的 コミットメントと読み替えることが可能で あるが、購買コミットメントは単なる将来的 な継続購買の意思として捉えられており、先 述の 2 つの研究で示された計算的要素は明 示的に含まれていない。

リレーションシップ・マーケティングおよ びその流れを汲んだブランド・コミットメン トの研究に扎いては、コミットメント概念の 多次元的性質と、モチベーションを異にする コミットメントが消費者の行動に対して明 確に異なった影響を及ぼすことが確認され ている。したがって、行動を導く態度として のコミットメントを議論するにあたり、その 源泉を考慮することの重要性は明白である。 しかし、先に記した 3 つ研究を取り上げ ても、ブランド・コミットメントの次元に関 する表記や捉え方には相違が見られ、ブラン ド・コミットメントの構造についての研究は いまだ途上にあると言えよう。本研究の目的 はこうした状況を改善するとともに、態度と してのコミットメントと実質的な行動との 関係をよりよく説明することにある。

\section{（3）ブランド・コミットメントと消費者の行 動との関係}

コミットメントは人間の一貫した行動や 行動の継続性などを規定する要因であるこ とがわかっており、消費者行動の分野では特 定ブランドの反復的な購買行動を説明する ために用いられることが最も多い。構成概念 であるコミットメントの捉え方、測定の尺度 については研究による差異があるという点 を念頭に置きつつ、ブランド・コミットメン トがどのような変数に影響を及ぼしている のかを先行研究の指摘からまとめておきた い。

ブランド・コミットメントの高い消費者に 見られる行動や特徴として、反復的あるいは 継続的な購買のほか、当該ブランドの他者 への推奨 (Fullerton 2003, 2005 ; HarrisonWalker 2001)、当該ブランドのネガティブ な情報に対しても動じない頑健な態度の保 持 (Ahluwalia et al. 2000)、マーケティング. コミュニケーションに打けるポジティブな 方向へのスピルオーバー効果 (Ahluwalia et al. 2001)、高い WTP (Chaudhuri and Holbrook 2002 ; Chaudhuri 2006 ; 清水 2007)、狭い考慮 集合サイズ (Desai and Raju 2007) などが指摘 されている。また最近の Raju et al. (2009) による研究では、特定ブランドへのコミット メントの高低によって、競合ブランドの露出 に対する情報処理行動が異なることも明ら かにされている。

ほとんどの研究はブランド・コミットメ ントを感情的な観点からの一次元で捉えて いることから上記の結果変数はブランドに 対するポジティブな態度がもたらすものと 考えることができる。前項で触れたブラン ド・コミットメントを多次元的に捉えた研 究、たとえば Fullerton(2005) は、感情的コ ミットメントならびに存続的コミットメン 
トが「再購買意図」、他者への推奨意図」に 及ぼす影響を検証している。結果は Gap を 対象ブランドとした場合、感情的コミットメ ントから再購買意図への回帰係数が 0.75 で あるのに対して存続的コミットメントから の影響は 0.13 にとどまっている。また推奨 意図に対しては感情的コミットメントから の回帰係数が 0.81 であるのに対し、存続的 コミットメントは-0.11 とマイナスの影響を 示していた。さらに、対象ブランドを Tim Hortons とした場合にも感情的コミットメン トから他者への推奨意図は 0.59、存続的コ ミットメントからの影響は -0.34 であった。 再購買意図への影響は感情的コミットメン トが 0.75 という高い回帰係数を示したもの の、存続的コミットメントはパスが有意とな らずその影響自体が認められなかった。

消費者パッケージグッズの広範なブラン ドを対象に行われた Chaudhuri(2006)の研究 では、消費者の態度的コミットメントは当該 ブランドの相対価格に対して影響を及ぼし ているものの（回帰係数は $0.22 ） 、$ 市場シェ アに対する影響力はなく、反対に購買コミッ トメントは市場シェアに対する影響力をも つ一方（回帰係数は 0.25）、相対価格との関 連性は認められなかった。

先行研究を概観すると、ブランド・コミッ トメントの影響が単純な反復購買という行 動的結果にとどまらず消費者の複雑な情報 処理にまで及ぶこと、またブランド・コミッ トメントの源泉に基づく質的差異を考慮す ることでその影響力の違いや、もたらされる 結果そのものの違いまでもが解明できるこ とがわかる。

\section{3. ブランド・コミットメントの構造に関 する仮説と分析}

(1) ブランド・コミットメントの構造に関す る仮説の設定

前節で記したように、ブランド・コミット メントはブランド・ロイヤルティという行動 的な指標に対し、消費者の態度を捉える概念 として主に感情的な側面から言及されてき た。また、関与の一部という観点では、当該 ブランドが製品クラスの中で唯一受容可能 な選択肢として消費者の心に根ざしている 程度（Traylor 1981）として捉えることも可 能である。さらに情緒的・感情的な源泉に対 して、スイッチング・コストやサイドベット を源泉とする認知的・計算的な性格もブラン ド・コミットメントを構成すると考えられて いる。本研究では既存の知見を融合させる形 で下記のようにブランド・コミットメントの 3 つの次元を仮定する。

\section{(1) 感情的コミットメント}

ブランド・コミットメントが単一の概念と して捉えられるときには、一般にブランドに 対する感情的あるいは心理的愛着、つまり感 情的コミットメントとして操作化されてい る。マーケティング・リレーションシップ招 よび組織コミットメントの議論では、感情的 コミットメントの源泉は相手あるいは組織 との価值の共有や同一視、愛着にあると考え られる (Bansal et al. 2004 ; Fullerton 2003, 2005 ; Gruen et al.2000)。また、消費者の コンテクストでは、製品・サービスの提供者 やブランドに対する信頼、取引に打ける楽し さ、友好性などによってその存在が確認され ている (Price and Arnould 1999)。リレー ションシップの基本が相手に対する肯定的 な感情にあることは言うまでもなく、商取引 の状況であっても関係性の本質は、信頼を 
ベースとした感情的コミットメントにある (Joshi and Arnold 1997)。

コミットメントを多次元的に捉えた既存 研究に打いて心理的・情緒的源泉をもつ感情 的次元はほほ例外なく指摘され実証的な結 果も多数提出されていることから、ブラン ド・コミットメントを構成する一次元として 感情的コミットメントを想定する。

感情的コミットメントが関係の継続や特 定ブランドの再購買に対してマイナスの影 響をもつことを示した研究は存在していな いが、感情的コミットメントが生じた背景に ついて清水（2007）からひとつの興味深い 知見を得ることができる。2005 年から 2006 年にかけて消費者の態度変化を探った同研 究の結果は、信頼やなじみといった感情的な コミットメントが高いほど消費者がそのブ ランドを特売で購入する確率が高く、さら にその特売購入経験が感情的コミットメン トを高めるというものである。この結果か ら、信頼やなじみのといった取引の過程で消 費者が一般的に抱きやすい感情、またリレー ションシップの基礎となる感情をもってブ ランドへの強い支持があると判断するには 十分でない可能性を指摘できる。

\section{(2) 計算的コミットメント}

社会心理学分野に打いて Rusbult(1980a, 1980b) はコミットメントが生じるメカニ ズムを投資モデルおよび相互依存性理論 (Thibaut and Kelly 1959) によって説明して いる。そこでは対人関係を対象に、同じ関係 にとどまるか否かの判断が、現在の関係にお ける相互作用の成果と比較水準（現在の関係 の魅力度、満足度を測る基準) と代替の比 較水準 (入手可能な代替選択肢の質、魅力 度を測る基準) の 3 つを比較することによっ て導かれると考えられている。現在の関係
が比較水準を超える成果をもたらしていれ ば当然その関係にとどまろうという意思が 働くであろうし、現在の関係に不満な場合で も、魅力的な代替選択肢がなかったり、代替 にスイッチするために負担するコストが大 きすぎたりすれば、やはり現在の関係が継続 するのである。この考え方は、ブランドのパ フォーマンスと消費者自身の満足水準打よ び当該ブランドに対する満足度、さらに市場 に打ける代替選択肢の入手可能性やスイッ チング・コストなどの議論に置き換えること が可能で、特にスイッチング・コストの知覚 という観点はブランド・コミットメントの性 格を規定する重要な要素となるだろう。

組織コミットメントの研究に打いても、同 様の性質をもったコミットメントが識別さ れている。Becker(1960) が唱えたサイドベッ 卜理論によれば、従業員は知らず知らずのう ちに労力や時間を含むさまざまな投資を組 織に対して行うことによってサイドベット を形成し、組織を離れるという選択肢を自ら なくしていく。つまり組織を去るときにはサ イドベットが失われ、新しい組織でまた新た にさまざまな負担を背負わなくてはならな くなることから、従業員は同じ組織にとど まることを選択するという。これは広く用 いられる Allen and Meyer（1990）の3 分類 の存続的コミットメントに当たり ${ }^{2}$ 、ブラン ド・コミットメントのコンテクストに扔い ても Fullerton(2005) によって指摘されてい る。感情的コミットメントがポジティブであ るのに対して、計算的コミットメントは文字 通り広い意味での損得を考慮した上でのコ ミットメントであり、消極的なコミットメン トであると言える。既存研究で明らかにされ ているように、ネガティブな動機を背景とし たコミットメントであっても行動の一貫性 や継続を促進することから、ブランド・コ 
ミットメントのネガティブな局面も考慮す る必要がある。したがって、ブランド・コミッ トメントの 2 つ目の次元として計算的コミッ トメントを想定する。

\section{(3) 陶酔的コミットメント}

前節で触れたとおり、ブランド・コミッ トメント概念は消費者関与の研究潮流に打 いて関与の一部あるいは下位概念として提 示されたという経緯がある。Lastovicka and Gardner(1977) は、ブランド・コミットメン トを消費者が特定ブランドの選択に示す強 いこだわりと定義し、それはつまり製品クラ ス内の特定ブランドに対する心理的な愛着 (psychological attachment) であると説明し ている。さらにブランド・コミットメントは 製品クラス内の特定ブランドが唯一受容可 能な選択肢として消費者の心の中に根ざし ている程度を反映し（Traylor 1981）、この コミットメントが究極に達すると消費者の 想起集合はただ一つのブランドによって占 められ確実に当該ブランドが選択されると いう。

製品関与とブランド・コミットメントと の関連性を整理した青木（2004）によると、 関与は「対象や状況（ないし課題）といった 諸要因によって活性化された消費者個人内 の目標志向的な状態であり、消費者個人の 価值体系の支配を受け、当該対象や状況（な いし課題）に関わる情報処理や意思決定の水 準およびその内容を規定する状態変数」であ る。これに従えば、対象特定的関与としての ブランド・コミットメントは当該ブランドが 個人の価值体系に扎いていかに中心的で、重 要な価值の実現と梁く結びついているかに よって規定される。

ブランド・リレーションシップ研究に打 いて先駆的かつ斬新なアイデアを提示した
Fournier(1998) はアニミズムの考え方を導入 し、ブランドと消費者との関係を能動的な パートナーと捉えている。彼女が行ったライ フ・ヒストリー分析からはブランド・リレー ションシップの性質を示す次元の一つに「愛 と情熱 (love and passion)」という消費者と ブランド間の強い感情的絆が見出されてい る ${ }^{3}$

消費者がブランドとの関係に扎いて、いか に自己関連的な価值を知覚し、信頼や愛着と いった一般的な感情以上の、排他的で強い思 い入れを有するかについては既存研究にお いて十分な検討がなされてこなかった盲点 であると言える。そこで3つ目の次元として、 より強い思い入れを反映した陶酔的コミッ トメントを想定する。

陶酔的コミットメントは、心理的あるいは 情緒的な要素が多分に含まれているという 点で感情的コミットメントとの相関が高い と予想されるが、先述のと打りブランドと消 費者の関係は既存の感情的コミットメント で捉えきれない部分がある。したがって、リ レーションシップ・マーケティングや組織コ ミットメントの議論では指摘されていない 陶酔的コミットメントを 3 つ目のコミット メント次元として組み入れることで、新しい 発見があるものと期待する。

\section{（2）ブランド・コミットメント次元の妥当性 の検証}

上述した「感情的コミットメント」、「計 算的コミットメント」、「陶酔的コミットメ ント」というブランド・コミットメントの 3 次元構造が妥当性を持つか否かを検討する ために、3つのモデルを設定し比較する。焦 点は既存研究で検討されたことのない陶酔 的コミットメントの存在が認められるかど うかである。感情的コミットメントと計算的 
コミットメントについては概念の弁別性に 問題がないと予想されるが、感情的コミット メントと陶酔的コミットメントについては、 別個に捉えることが可能かどうかの詳細な 検討を要する。そのため、図 1 中央のように 陶酔的コミットメントと感情的コミットメ ントの測定尺度をまとめて 1 つの因子を構成 した 2 次元の対立モデルを置いて比較する。 感情的コミットメントは当該ブランドに対
する信頼およびなじみや愛着に関する 2 項 目、計算的コミットメントはスイッチング • コストの知覚を主とした 3 項目、陶酔的コ ミットメントは自己との関連性打よび当該 ブランドに対する排他的支持を含む 3 項目 で測定した。いずれも 4 段階のリカート尺度 を用いた。各測定尺度の詳細については結果 の表 2 を参照されたい。

図 1 仮説モデルと対立モデル（左からモデル I，II，II）

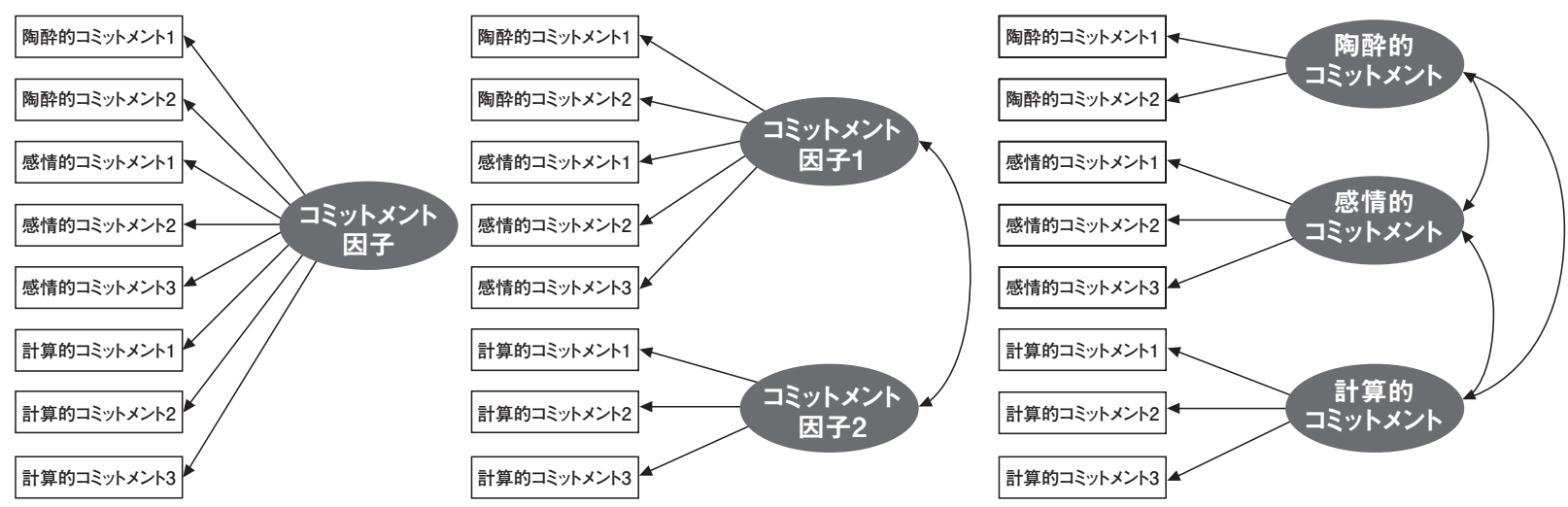

上記のモデルは、株式会社読売広告社の協 力により、同社が毎年行っている生活者意識 調査『CANVASS』の 2008 年度版データを 用いて分析した。データは関東 $30 \mathrm{~km}$ 圈内、 大阪 $20 \mathrm{~km}$ 圈内に居住する満 13 歳〜 69 歳の 一般男女 1715 人から留め置き法を用いて収 集されたものである。分析にはシャンプー、 ビール、発泡酒・第 3 のビールの複数カテ ゴリーのデータを用いる。このうち、シャ ンプーと発泡酒・第 3 のビールについては 2008 年度に同サンプルに対し 2 回の調査が 実施されているので 4 、3 カテゴリー計 5 グ ループの分析が可能である。

質問票は、たとえばビールであれば、市場 に打ける主要 20 ブランドのうち過去半年以 内に購入回数が多かった上位 2 ブランドを 被験者に選択してもらい、それぞれにコミッ
トメントの質問項目に回答してもらう形を とった。

提示した 3 つのモデルについて確証的因子 分析を行い、モデルの当てはまりを検討した (表 1 を参照)。一次元のモデルは極めて当て はまりが悪く、陶酔的コミットメントと感情 的コミットメントを 1 つの構成概念としてま とめたモデル II も許容範囲を超えている。モ デル IIIIのみが GFI、AGFI、RMSEA の適合 度指標に打いて十分な值を示しており、3つ のモデルの AIC を比較してもモデル III が明 らかにデータとの適合性が高いことがわか る。またこれらの 3 つのモデルは入れ子状 の関係にあるため $\chi^{2}$ 值の差も $\chi^{2}$ 分布すると いう性質を利用してモデル間の適合度の差 を統計的に検定することができる（Widaman 1985)。特にモデル II とIIIに関して言えば、 
すべてのカテゴリーにおいてその差は $1 \%$ 水 準で有意であり、モデル III を採択することの 妥当性が示された。またこれらの結果から 3 つの構成概念の弁別妥当性が確認できる （Baggogi 1994 ；Widamann 1981）。弁別妥当 性は概念間の相関係数が 1 と有意に異なる ことをチェックすることによっても確認さ れた。収束妥当性は、構成概念とそれを構 成する項目間の相関が 0.5 以上 (Hildebrandt 1987 ; Steenkamp and Trijp 1991）であるこ
とを基準として検討した結果、すべての項 目の推定值が $1 \%$ 有意水準で十分に 0.5 を上 回った。

測定尺度の内的一貫性についてはクロン バックの $\alpha$ 係数を用いて検討した。表 3 に 示されるようにすべてに沶いて 0.7 以上の值 を示しており（Baggogi 1994）、測定尺度の 信頼性は確保されている。以上の結果を総合 し、仮定したブランド・コミットメントの 3 次元モデルは妥当であると結論づけられる。

表 1 ブランド・コミットメント構造の検討（モデルの比較）

モデル I
\begin{tabular}{|l|r|r|r|r|r|}
\hline 適合度指標 & 発泡酒(1) & 発泡酒(2) & ビール & シャンプー1 & シャンプー2 \\
\hline$X^{2}$ & 1951.25 & 2191.01 & 1830.75 & 2505.16 & 2457.32 \\
df & 21 & 21 & 21 & 21 & 21 \\
p & 0.000 & 0.000 & 0.000 & 0.000 & 0.000 \\
GFI & 0.598 & 0.582 & 0.621 & 0.595 & 0.598 \\
AGFI & 0.308 & 0.283 & 0.351 & 0.306 & 0.311 \\
RMSEA & 0.31 & 0.331 & 0.298 & 0.309 & 0.303 \\
AIC & 1981.01 & 2221.01 & 1860.00 & 2535.16 & 2487.32 \\
\hline
\end{tabular}

モデル I

\begin{tabular}{|l|r|r|r|r|r|}
\hline 適合度指標 & 発泡酒 1 & 発泡酒(2) & ビール & シャンプー1 & シャンプー2 \\
\hline$X^{2}$ & 524.37 & 678.64 & 509.17 & 604.67 & 675.92 \\
df & 20 & 20 & 20 & 20 & 20 \\
p & 0.000 & 0.000 & 0.000 & 0.000 & 0.000 \\
GFI & 0.876 & 0.851 & 0.889 & 0.889 & 0.877 \\
AGFI & 0.777 & 0.732 & 0.799 & 0.801 & 0.779 \\
RMSEA & 0.162 & 0.187 & 0.159 & 0.153 & 0.161 \\
AIC & 556.37 & 710.64 & 541.17 & 636.67 & 707.92 \\
\hline
\end{tabular}

モデルIII
\begin{tabular}{|l|r|r|r|r|r|}
\hline 適合度指標 & 発泡酒(1) & 発泡酒(2) & ビール & シャンプー1 & シャンプー2 \\
\hline$X^{2}$ & 61.17 & 74.81 & 33.29 & 55.28 & 39.13 \\
df & 12 & 12 & 12 & 12 & 12 \\
p & 0.000 & 0.000 & 0.000 & 0.000 & 0.000 \\
GFI & 0.985 & 0.981 & 0.991 & 0.989 & 0.992 \\
AGFI & 0.957 & 0.943 & 0.974 & 0.968 & 0.977 \\
RMSEA & 0.062 & 0.074 & 0.043 & 0.054 & 0.042 \\
AIC & 107.18 & 122.81 & 81.90 & 103.28 & 87.13 \\
\hline \multicolumn{7}{|c|}{$n=958$} & $n=947$ & $\mathrm{n}=973$ & $\mathrm{n}=1242$ & $\mathrm{n}=1263$
\end{tabular}

表 2 クロンバックの $a$ による信頼性の検討

\begin{tabular}{|c|c|c|c|c|c|c|}
\hline 構成概念 & 質問項目 & 発泡酒(1) & 発泡酒(2) & ビール & シャンプー1) & シャンプー2 \\
\hline 陶酔的コミットメント & $\begin{array}{l}\text { 自分にとってはこのブランドしか考えられない } \\
\text { このブランドだったら多少ほかのブランドより高くても買う } \\
\text { このブランドは自分にぴったり合っている }\end{array}$ & 0.81 & 0.83 & 0.87 & 0.88 & 0.79 \\
\hline 感情的コミットメント & \begin{tabular}{|l} 
このブランドを信頼している \\
このブランドに対して愛着や親しみを抱いている
\end{tabular} & 0.79 & 0.83 & 0.76 & 0.80 & 0.79 \\
\hline 計算的コミットメント & $\begin{array}{l}\text { ほかのブランドを検討するのは面倒である } \\
\text { ほかのブランドを買って失敗したくない } \\
\text { あまり深く考えていない、なんとなくこのブランドになる }\end{array}$ & 0.73 & 0.72 & 0.78 & 0.72 & 0.76 \\
\hline
\end{tabular}


4. ブランド・コミットメントと購買行動 に関する仮説と検証

（1）ブランド・コミットメントと購買行動の 関係に関する仮説の設定
ブランド・コミットメントの 3 次元構造が 確認されたところで、これら各次元と消費者 の行動変数との関係について解明していく。 仮説モデルは図 2 のとおりである。

図 2 ブランド・コミットメントと購買行動に関する仮説モデル

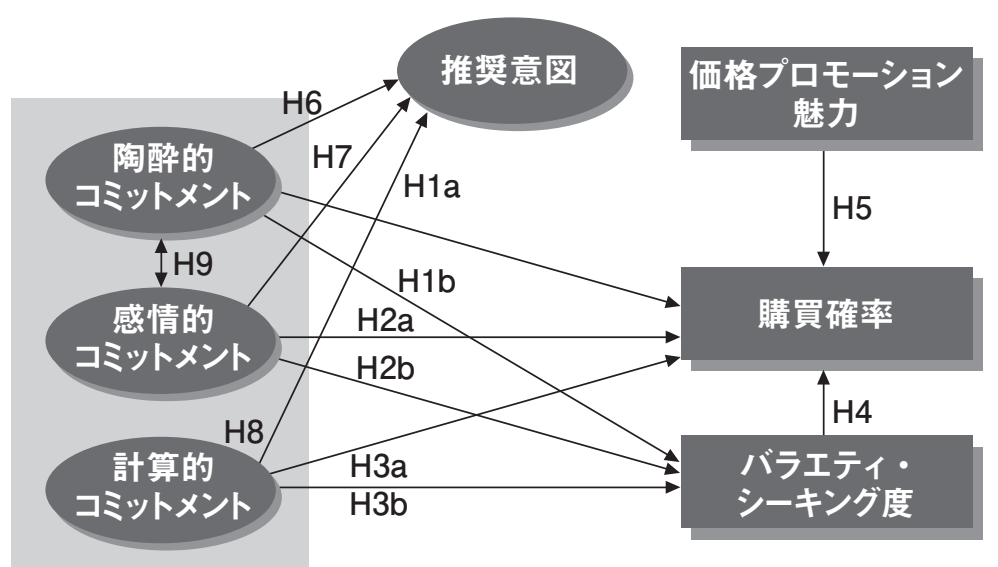

第 2 節においてブランド・コミットメン トの影響範囲をまとめたように、ブランド・ コミットメントがもたらす結果として最も 頻繁に確認されている変数は、当該ブランド の再購買意困である。ここで「意図」となる のは多くの研究で消費者の実質的な行動で はなく質問票による意思の測定にとどまっ ているからである。本研究では消費者が実際 に過去に行った行動の尺度を用いて、コミッ トメントとの関係を明らかにする。

仮説モデルでは陶酔的コミットメント、感 情的コミットメント、計算的コミットメント のそれぞれから購買確率およびバラエティ・ シーキング度へのパスが引かれている（H1a 〜 H3b)。ここで示した購買確率は前節での 分析に用いた調査の中で、1 番よく購入した ブランド、 2 番目によく購入したブランドの 購買頻度を「10」を最大值として数字で回 答したもらったデータである。すべての購買 機会において $\mathrm{A}$ というブランドを必ず購入 していたという被験者の場合、1 番目のブラ ンドについての回答しかなく、購買確率は
10 となる。

Bansal et al. (2004)、Fullerton(2003, 2005)、Gruen et al.(2004) など複数の既存研 究に打いて、感情的コミットメントは顧客維 持や再購買に対してプラスの強い影響力を もつことが確認されている。したがって、こ こでは感情的コミットメントが購買確率に 対してプラスの影響をもつと仮定する。また 計算的コミットメントから購買確率へのパ スについても、先述した既存研究の中で弱い ながらもプラスの影響が実証されているこ とに基づいて設定した。陶酔的コミットメン 卜は文字通り当該ブランドに対する思い入 れとこだわりを最も強く反映した概念であ るため、購買確率に対して強いプラスの影響 を持つと仮定する。

$\mathrm{H} 1 \mathrm{a}, \mathrm{H} 2 \mathrm{a} \mathrm{H} 3 \mathrm{a}$ ：陶酔的コミットメント／感 情的コミットメント /計算 的コミットメントは購買確 率に対してプラスの影響を もつ。 
バラエティ・シーキング度は、調査票内 で提示した市場の主要ブランドについて（い ずれのカテゴリーもブランド数は 20 前後)、 被験者が調査対象期間中に購買したことが あると回答したブランドの数で測定された。 特定ブランドの購買確率が高いことと他ブ ランドの購買経験の多さは理論的には相反 すると考えられるため、3つのブランド・コ ミットメント次元からバラエティ・シーキン グ度に対してはマイナスの影響があると仮 定する。加えて、バラエティ・シーキング度 が高いと特定ブランドの購買確率は下がる と考えられることから H4 を設定した。

$\mathrm{H} 1 b, \mathrm{H} 2 \mathrm{~b}, \mathrm{H} 3 \mathrm{~b}$ ：陶酔的コミットメント／感 情的コミットメント／計算 的コミットメントはバラエ ティ・シーキング度に対し てマイナスの影響をもつ。

$\mathrm{H} 4$ : バラエティ・シーキング度は購買確率 に対してマイナスの影響をもつ。

さらに、購買確率に対してはインストア・ プロモーションとして購買意思決定に多大 な影響をもつと予想される価格プロモー ションを考慮した。価格プロモーション魅力 の測定には「よく值引きされているので購入 している」という単一の尺度を用いている。

$\mathrm{H} 5$ ：価格プロモーション魅力は購買確率に 対してプラスの影響をもつ。

そして、H6、H7 は陶酔的コミットメン トおよび感情的コミットメントから推奨意 図へのプラスの影響を仮定した。これらは Fullerton (2003, 2005) や Harrison-Walker (2001)に扎いて感情的コミットメントから推
奨行動へのプラスの影響が実証されている ことに基づく。一方、計算的コミットメン 卜は推奨行動へのマイナスの影響が明らか にされていることから、H8 として計算的コ ミットメントから推奨意図へのパスを引い た。情報発信者であるインフルエンサーの 重要性が指摘されたり（山本 2005）、消費者 間のネットワークを利用したレコメンデー ションの効果が指摘されるなど（山本・阿部 2007)、クチコミの影響が近年のマーケティ ングに打ける大きな論点となっていること を考えると、コミットメントと消費者の情報 発信行動との関連性を探ることは意義があ ると考えられる。推奨意罒は、「このブラン ドのよさを人に話したい」、「ほかの人にもこ のブランドを高く評価してもらいたい」の 2 項目を 4 段階のリカート尺度で測定した。

H6：陶酔的コミットメントは推奨意図に対 してプラスの影響をもつ。

$\mathrm{H} 7$ : 感情的コミットメントは推奨意図に対 してプラスの影響をもつ。

H8：計算的コミットメントは推奨意図に対 してマイナスの影響をもつ。

最後に前節で行ったブランド・コミットメ ント構造の分析に基づき、陶酔的コミットメ ントと感情的コミットメントのプラスの相 関関係を仮定する。

H9 : 陶酔的コミットメントと感情的コミッ トメントにはプラスの相関関係がある。

\section{（2）仮説モデルの検証}

前節で記したデータを用いて図 2 の仮説 モデルを検証した結果、いずれのカテゴリー に打いても十分な適合度によりモデルが採 択された（表 3 参照）。モデル内の構成概念 
は前節において導出された 3 つのコミット メントに推奨意図を加えた 4 つであり、推 奨意困の測定尺度の信頼性も他と同様にク ロンバック $\alpha$ を用いて検討した。その結果、 発泡酒(1) と (2)で $\alpha=0.85$ 、ビールとシャン

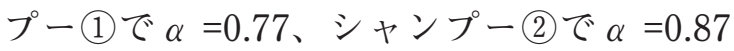
の值を示し、尺度の信頼性が確認できた。ま た、収束妥当性は各構成概念に対してすべ ての項目が標準化推定値 0.5 以上の值を示し た（すべて $1 \%$ 水準をクリア）ことにより確 認された。さらに内的一貫性と弁別妥当性を Fornell and Lacker(1981)にしたがって検討 した結果 (表 4 )、Composite Reliability は 0.7 以上、Average Variance Extracted (AVE) は 0.5 以上という基準 (Hair et al. 1998) を すべてに打いて満たしている。Fornell and Lacker(1981) は、各構成概念の AVE がモデ ル内のすべての潜在変数間の平方相関を上 回っていることが弁別妥当性の根拠になる と説明しており、表 5 と合わせて見ると結 果はその基準もクリアしていた。以上のこと から、仮定した測定モデルは妥当なものと判 断できる。

続いて構造モデルについて見ていく。仮説 との顕著な違いがあるところでは H6（価格 プロモーション魅力 $\rightarrow$ 購買確率) において結 果に大きなばらつきが生じ、発泡酒以外の力 テゴリーでは有意とならなかった。そのほか H3a（計算的コミットメント $\rightarrow$ 購買確率）は、
発泡酒(2)を除き棄却された。

$\mathrm{H} 1 \mathrm{a}$ (陶酔的コミットメント $\rightarrow$ 購買確率)、 $\mathrm{H} 2 \mathrm{a}$ （感情的コミットメント $\rightarrow$ 購買確率）は すべてに扔いて仮説が支持され、強いプラス の影響が確認された。H1b（陶酔的コミット メント $\rightarrow$ バラエティ・シーキング度)、H $2 \mathrm{~b}$ (感 情的コミットメント $\rightarrow$ バラエティ・シーキン グ度）については、いずれも影響の存在が確 認できたが、H2b はその影響が予想に反して プラスとなっており、ブランドへの感情的コ ミットメントが高くてもバラエティ・シーキ ング行動をとるという結果が示された。推奨 意図への影響を検証した H6（陶酔的コミッ トメント $\rightarrow$ 推奨意図)、H7（感情的コミット メント $\rightarrow$ 推奨意困)、H8（計算的コミットメ ント $\rightarrow$ 推奨意図）の結果は、H6、H7 が全面 的に支持されたものの、H8については発泡 酒とビールのカテゴリーで非常に弱いプラ スの影響が確認され仮説と反対の符号での 支持、シャンプーのカテゴリーでは影響自体 が認められなかった。H4（バラエティ・シー キング度 購買確率）はすべてのデータで支 持され、マイナスの関係にあることが示され た。

仮説を置かなかったパスの中で修正指標 を参照し、理論的に許容できると判断された 計算的コミットメントと価格プロモーショ ン魅力間の相関はモデルに含めることとし た。表 6 にパスの推定值が示されている。 
表 3 最終モデルの適合度

\begin{tabular}{|l|r|r|r|r|r|}
\hline \multicolumn{1}{|c|}{ 適合度指標 } & 発泡酒(1) & 発泡酒(2) & ビール & シャンプー(1) & シャンプー2 \\
\hline$X^{2}$ & 267.4 & 242.0 & 267.0 & 254.6 & 241.1 \\
$\mathrm{df}$ & 50 & 50 & 50 & 50 & 50 \\
$\mathrm{p}$ & 0.000 & 0.000 & 0.000 & 0.000 & 0.000 \\
$\mathrm{GFI}$ & 0.961 & 0.967 & 0.964 & 0.973 & 0.968 \\
$\mathrm{AGFI}$ & 0.938 & 0.931 & 0.927 & 0.947 & 0.937 \\
$\mathrm{RMSEA}$ & 0.066 & 0.064 & 0.067 & 0.055 & 0.048 \\
\hline
\end{tabular}

表 4 内的一貫性と弁別妥当性の検討

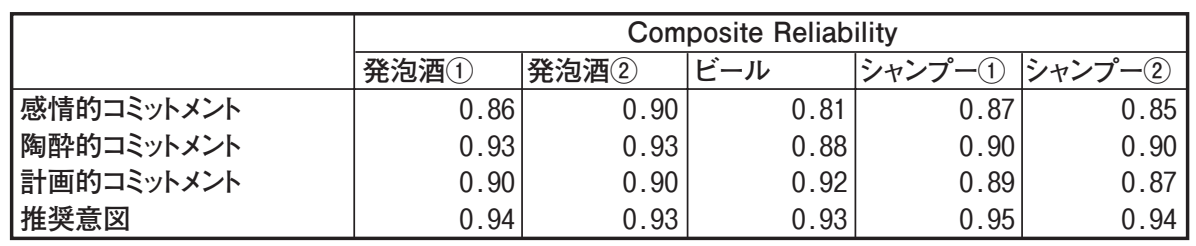

\begin{tabular}{|l|r|r|r|r|r|}
\hline & \multicolumn{6}{|c|}{ AVE(Average Variance Extracted) } \\
\cline { 2 - 6 } & 発泡酒1 & 発泡酒(2) & ビール & シャンプー1) & シャンプー2 \\
\hline 感情的コミットメント & 0.70 & 0.71 & 0.66 & 0.70 & 0.70 \\
陶酔的コミットメント & 0.63 & 0.65 & 0.65 & 0.64 & 0.64 \\
計画的コミットメント & 0.69 & 0.68 & 0.70 & 0.70 & 0.70 \\
推奨意図 & 0.64 & 0.65 & 0.66 & 0.66 & 0.66 \\
\hline
\end{tabular}

\section{表 5 因子間相関係数}

\begin{tabular}{|c|c|c|c|c|c|c|}
\hline & & 発泡酒(1) & 発泡酒(2) & ビール & シャンプー1) & シャンプー(2) \\
\hline 感情的コミットメント 〈--〉 & 計算的コミットメント & -0.01 & 0.17 & 0.06 & 0.01 & 0.01 \\
\hline 陶酔的コミットメント $\langle--\rangle$ & 計算的コミットメント & 0.05 & 0.29 & 0.10 & 0.11 & 0.04 \\
\hline 感情的コミットメント 〈--〉 & 陶酔的コミットメント & 0.62 & 0.57 & 0.66 & 0.63 & 0.63 \\
\hline 感情的コミットメント 〈--〉 & 推奨意図 & 0.64 & 0.67 & 0.64 & 0.62 & 0.66 \\
\hline 陶酔的コミットメント $\langle--\rangle$ & 推奨意図 & 0.70 & 0.68 & 0.66 & 0.65 & 0.63 \\
\hline 計算的コミットメント $\langle--\rangle$ & 推奨意図 & $* * 0.07$ & 0.28 & 0.13 & 0.02 & 0.00 \\
\hline
\end{tabular}

相関係数の ${ }^{* *}$ は $5 \%$ 水準、そのほかは $1 \%$ 水準で有意。斜体は茟却。

表 6 仮説パスの推定値

\begin{tabular}{|c|c|c|c|c|c|c|c|c|}
\hline 仮説 & & パス & & 発泡酒(1) & 発泡酒(2) & ビール & シャンプー1) & シャンプー2) \\
\hline $\mathrm{H} 1 \mathrm{a}$ & \begin{tabular}{|l} 
購買確率 \\
\end{tabular} & $\langle--$ & 陶酔的コミットメント & 0.50 & 0.75 & 0.81 & 1.04 & 0.92 \\
\hline $\mathrm{H} 1 \mathrm{~b}$ & バラエティシーキング度 & $\langle--$ & 陶酔的コミットメント & -0.69 & -0.34 & $*-0.24$ & -0.38 & -0.52 \\
\hline $\mathrm{H} 2 \mathrm{a}$ & 購買確率 & $\langle--$ & 感情的コミットメント & 0.75 & 0.68 & $* 0.50$ & $* 0.38$ & 0.69 \\
\hline $\mathrm{H} 2 \mathrm{~b}$ & バラエティシーキング度 & $\langle--$ & 感情的コミットメント & 0.83 & 0.63 & $* * 0.46$ & 0.64 & 0.60 \\
\hline н3а & 購買確率 & $\langle--$ & 計算的コミットメント & n.s. & $* *-0.51$ & n.s. & n.s. & n.s. \\
\hline H3b & バラエティシーキング度 & $\langle--$ & 計算的コミットメント & $* *-0.34$ & n.s. & $* *-0.37$ & $* *-0.25$ & -0.39 \\
\hline $\mathrm{H} 4$ & 購買確率 & $\langle--$ & 価格プロモーション魅力 & 0.24 & $* 0.18$ & n.s. & n.s. & n.s. \\
\hline $\mathrm{H} 5$ & 購買確率 & $\langle--$ & バラエティシーキング度 & -0.26 & -0.26 & -0.24 & -0.64 & -0.56 \\
\hline $\mathrm{H} 6$ & 推奨意図 & $\langle--$ & 陶酔的コミットメント & 0.60 & 0.57 & 0.73 & 0.60 & 0.59 \\
\hline $\mathrm{H} 7$ & 推奨意図 & $\langle--$ & 感情的コシットメント & 0.34 & 0.56 & 0.38 & 0.49 & 0.47 \\
\hline $\mathrm{H} 8$ & 推奨意図 & $\langle--$ & 計算的コミットメント & $* * 0.05$ & 0.16 & 0.12 & n.s. & n.s. \\
\hline $\mathrm{H} 9$ & ブランド陶酔 & $\langle--$ & 感情的コミットメント & 0.22 & 0.17 & 0.13 & 0.19 & 0.20 \\
\hline 追加 & 計算的コシットメント & $\langle--$ & 価格プロモーション魅力 & 0.11 & 0.10 & 0.17 & 0.18 & 0.11 \\
\hline
\end{tabular}

パス係数の * $10 \%$ 水準、 ${ }^{* *}$ は $5 \%$ 水準、そのほかは $1 \%$ 水準で有意。 


\section{(3) 結果からの考察}

仮説を検証した結果、ブランドに対する陶 酔的なコミットメントがあると購買機会に おける当該ブランドの選択確率が高くなり、 さらに Traylor(1981)の指摘を支持するよう に考慮集合が狭まる可能性も示唆された。信 頼や愛着をべースとする感情的コミットメ ントも同様にブランドの選択確率に対して プラスの影響を及ぼしているものの、概して 陶酔的コミットメントからの影響力を下回 る。陶酔的コミットメントにはブランドに 対する絶対的な思い入れやこだわりに加え、 コスト面での犠牲（高いWTP）の受容が含 まれている。ブランドにとって消費者のこう した態度を形成することは安定的な売上と 確固たる市場ポジションの獲得につながる と予想できる。陶酔的コミットメントと感情 的コミットメントの間には相関関係が認め られたが、その程度は想定していたほど大き くなかった。ブランドに対する信頼や愛着、 なじみと、ある種の犠牲を厭わず特定ブラン ドを選択し続けるという態度は別個のもの であり（構成概念の弁別妥当性の検定より）、 頻繁に指摘される「愛着」を醸成するだけで は十分でないと言える。それは、バラエティ・ シーキング変数に対する陶酔的コミットメ ントと感情的コミットメントの影響の違い からも示唆される。調査対象期間内（発泡 酒・第 3 のビールとビールのカテゴリーは 過去半年間、シャンプーカテゴリーは過去 1 年間）に市場にある当該カテゴリーのブラン ドをどれだけ購買したことがあるかを尋ね たバラエティ・シーキング変数に対し、感情 的コミットメントからはプラスのパスが認 められた。一方、陶酔的コミットメントから のパスはマイナスであり、陶酔的なコミット メントが高いと、他ブランドを購入したとい う実質的なスイッチ経験が少なくなる。つま
り、特定のブランドに対する感情的なコミッ トメントが高くとも、他ブランドへのスイッ チング行動が抑止されることはなく、排他 的な支持を得るためには陶酔的なコミット メントが必要だということである。

感情的コミットメントが陶酔的コミット メントに比べて弱い行動的ロイヤルティし かもたらさない理由として、感情的コミッ トメントのベースである信頼が購買におい てはもはや必要条件となっていること、な じみや愛着もそのきっかけや背景が何であ れ、購買や使用が重なることによって高まっ ていくものであるからだと考えられる。先 述した清水（2007）の結果はこれを裏付け ていると言えよう。

続いて、計算的コミットメントと購買確 率およびバラエティ・シーキング行動との 関係を見ていこう。発泡酒 2 回目のデータ を除いて「計算的コミットメント $\rightarrow$ 購買確 率」のパスは有意とはならず 5 、計算的コ ミットメントの影響は、低いバラエティ・ シーキング度を通じた間接的なものである ことがわかる。これは消極的な意味で同じ ブランドを使用し続ける人々の存在を示し ている。計算的コミットメントは当該ブラ ンドに対する強い思い入れや愛着といった エモーショナルな結びつきではなく、惰性 的あるいは種々のスイッチング・コスト回 避を代表した変数であるため、他ブランド の検討や購買を「しないこと」が結果とし て特定ブランドの反復購買に至っていると いうことである。従来のブランド・ロイヤ ルティ研究において問題視された表面的な ロイヤルティとはまさにこうした計算的コ ミットメントによって生じる反復購買を指 している。ブランドにとっては、こうした 計算的コミットメントも重要である。井上 （2007）では、市場シェアの高いブランドが 
消費者からの高い陶酔的コミットメント、感 情的コミットメントだけでなく、高い計算的 コミットメントによっても支えられている ことが明らかになっている。注意すべきポイ ントは計算的コミットメント「だけ」でない 点である。

本研究で提示した 3 次元からなるブラン ド・コミットメント尺度を用いてブランドを 診断すると、当該ブランドが消費者からどの ような態度をもって購買されているかがわ かる。ブランドが消費者の計算的コミットメ ントに支えられるようなポジションに意図 せず陥っているのであれば、発展的なブラン ドの構築ルートから外れていると認識した ほうがよいだろう。これは計算的コミットメ ントが店頭での「売られ方」を反映した唯一 の変数「価格プロモーション」とプラスの相 関関係にあることからも推測できる。

先に述べたように感情的コミットメント と陶酔的コミットメントは積極的な意味で 当該ブランドの選択を後押しするとともに、 近年、より影響力を増していると考えられる クチコミや他者への推奨に大きな役割を果 たす。これは計算的コミットメントには期待 できない効果であり、ブランド構築上の貢献 が大きいと考えられる。さらに、感情的コ ミットメントと陶酔的コミットメントはい ずれも他者への推奨意図に対してプラスの 影響を持っているが、すべてのデータに扎い て陶酔的コミットメントからのパス係数の ほうが大きいことが確認できた。

そのほか、価格プロモーション魅力から購 買確率へのパスについては発泡酒のカテゴ リーのみで有意となり、ビールおよびシャン プーについては棄却された。発泡酒という製 品カテゴリーの位置づけや、企業のプロモー ション活動から推測すると、值引きの魅力が 購買確率を上げるという結果には合点がい
く。今回の分析ではこのパスについてのみ顕 著なカテゴリーによる違いが見られたが、実 際にカテゴリーの性質による違いが生んだ 結果なのか否かの検討は今後の課題として 残されている。

\section{5. おわりに}

本研究では、ブランドと消費者との関係を 記述する概念としてのブランド・コミットメ ントに着目し、その性質を捉える 3 つの次元 を導出した。既存研究において指摘されてき た「感情的コミットメント」、「計算的コミッ トメント」の 2 次元に「陶酔的コミットメ ント」を加えることで、コミットメントがも たらす消費者の行動的結果がより深く説明 できるようにとなったことは重要な貢献で ある。従来、ブランドと消費者間の関係につ いては、いくつかの研究を除いて感情的な要 素のみで説明がなされてきた。そこに、クー ルな側面をもつ計算的コミットメントを考 慮したことも、関係の質的多様性を確認する ことにつながった。

ブランド・ロイヤルティ研究で指摘されて きたように、消費者の行動の観点だけでは、 ブランドを支持する強い態度が存在するの か否かを判断することができず、行動の安定 性や頑健性を予測することが難しい。本研究 の結果は、感情的コミットメント、計算的コ ミットメント、陶酔的コミットメントという 3 つのブランド・コミットメント (態度) が、 購買行動に対してそれぞれ異なった強さや プロセスで影響を及ぼすことを証明した。多 くの既存研究のようにコミットメントの影 響について消費者の意図レベルで測定する のではなく、実際の購買によるデータを用い て分析した点にも本研究のひとつの価值が あると思われる。今後は、コミットメントの もつ購買行動以外への影響も含めて検討す 
ることが求められる。それにより、ブランド

の強さや将来性を測る指標としてのコミッ トメントの活用範囲が広がるだろう。

また、分析単位を消費者から個々のブラ ンドレベルに拡張し、消費者から得ている コミットメントの強さとブランドの市場に おける成果との関係を明らかにしていくこ とも研究上大きな意義がある。Chaudhuri （2006）は唯一これらの関係に迫ろうとした 研究であり、実際に、消費者が抱くコミッ トメントのタイプによってブランドが市場 シェアを得られるか、高い相対価格を得られ るかの違いが生じることを明らかにしてい る。

強いブランドになるためには（シェアを獲 得するのか、高い相対価格を獲得するのかと いったタイプも含めて)、ブランドの購買者 である消費者とどのような関係性を構築す るかが大きな鍵を握っている。関係性の内実 を決定づけるブランド・コミットメントの適 切な把握とマネジメントの手法を導くため には、消費者の意思決定プロセス全体を視野 に入れたさらなる研究が必要であろう。

\section{〈謝辞〉}

本稿の執筆にあたっては、日本商業学会 第 59 回全国大会流通研究セッションチェア の慶應義塾大学清水聰教授に多大なご指導 を賜りました。また本研究を進めるにあたつ て、株式会社読売広告社より貴重なデータを ご提供いただきました。ここに記して深く御 礼申し上げます。

\section{〈参考文献〉}

Ahluwalia, R., R. E. Burnkrant, and H. R. Unnava (2000), "Consumer Response to Negative Publicity: The Moderating Role of Commitment," Journal of Marketing
Research, 37 (2), pp.203-214.

Allen, N and J. Meyer (1990), "The Measurement and Antecedents of Affective, Continuance and Normative Commitment to the Organization," Journal of Occupation Psychology, 63, pp.1-18.

Amine, A. (1998), "Consumers' True Brand Loyalty: The Central Role of Commitment," Journal of Strategic Marketing, 6(4), pp.305-319.

青木幸弘（2004）、「製品関与とブランド・コミッ トメント一構成概念の再検討と課題整理一」『季 刊マーケティングジャーナル』第 23 号第 4 巻、 25-51頁。

Bagozzi, R. P. (1994), "Measurement in Marketing Research: Basic Principles of Questionnaire Design," in Principles of Marketing Research, ed. R. P. Bagozzi, Blackwell Publishers, pp.1-49.

Bansal, H, G. Irvin, and S. Taylor (2004), "A Three-Component Model of Consumer Commitment to Service Providers," Journal of the Academy of Marketing Science, 32(3), pp.234-250.

Becker, H. (1960), "Notes on the Concept of Commitment," American Journal of Sociology, 66, pp. 32-42.

Chaudhuri, A. and M. B. Holbrook (2002), "Product-class Effects on Brand Commitment and Brand Outcomes: The Role of Brand Trust and Brand Affect," Journal of Brand Management, 10(1), pp.33-58.

Chaudhuri, A. (2006), Emotion and Reason in Consumer Behavior, Butterworth and Heinemann.

Coulter, R., L. Price, and L. Feick (2003), "Rethinking the Origins of Involvement and Commitment: Insights from Post-Socialist 
Central Europe," Journal of Consumer Research, 30(2), pp.151-168.

Dansai, K. K. and S. Raju (2007), “Adverse Influence of Brand Commitment on Consideration of and Preference for Competing Brands," Psychology and Marketing, 24(7), pp.595-614.

Dwyer, F. R., P. H. Schurr, and S. Oh (1978), "Developing Buyer-Seller Relationships," Journal of Marketing, 51(2), pp.11-27

Fornell, C and D. F. Lacker (1981), "Evaluating Structural Equation Models with Unobservable Variables and Measurement Error," Journal of Marketing Research, 18(3), pp.39-50.

Fournier, S. (1998), "Consumers and Their Brands: Developing Theory in Consumer Research," Journal of Consumer Research, 24(4), pp.343-373.

Fullerton, G. (2003), “When Does Commitment Lead to Loyalty?" Journal of Service Research, 5(4), pp.333-344.

Fullerton, G. (2005), "The Impact of Brand Commitment on Loyalty to Retail Service Brands," Canadian Journal of Administrative Science, 22(2), pp.97-110.

Gruen, T., J. Summers, and F. Acito (2000), "Relationship Marketing Activities, Commitment, and Membership Behaviors in Professional Associations," Journal of Marketing, 64(3), pp.34-49.

Gundlach, G., R. Achrol, and J. Mentzer (1995), "The Structure of Commitment in Exchange," Journal of Marketing, 59(1), pp.78-92.

畑井佐織（2004）「消費者とブランドの関係の構 造と測定尺度の開発」『消費者行動研究』第 10 巻 $1 \cdot 2$ 号、pp. 17-41.

Hiar, J. F. Jr., R. E. Anderson, R. L. Tatham, and W.C. Black (1998), Multivariate Data
Analysis $5^{\text {th }}$ ed., Upper Saddle River.

Harrison-Walker (2001), “The Measurement of Word-of Mouth Communication and an Investigation of Service Quality and Customer Commitment as Potential Antecedents," Journal of Service Research, 4(1), pp.60-75. 井上淳子 (2003)、「リレーションシップ・マー ケティングにおけるコミットメント概念の検 討：多次元性の解明と測定尺度開発に向け て」『早稲田大学商学研究科紀要』第 57 号、 pp.81-96.

井上淳子（2007）「ブランド・コミットメントと ブランドカ」第 35 回日本消費者行動研究学会 報告．

Hildebrandt, L. (1987), "Consumer Retail Satisfaction in Rural Areas: A Reanalysis of Survey Data," Journal of Economic Psychology, 8(1), pp.19-42.

Joshi, A and S. Arnold (1997), “The Moderating Effect of Relational Norms on Buyer-Supplier Dependence-Opportunism Relationship," Psychology and Marketing, 14(8), pp.823-845.

Lastvicka, J. and D. M. Gardner (1978), Components of Involvement, in J. L. Maloney and B. Silverman eds., Attitude Research Plays for High Stakes, American Marketing Association, pp.53-73.

Moorman, C., G. Zaltman, and R. Deshpande (1992), "Relationship between Providers and Users of Marketing Research: The Dynamics of Trust within and between Organizations," Journal of Marketing Research, 29(3), pp.314-329.

Price, L. and E. Arnold (1999), "Commercial Friendship: Service Provider-Client Relationships in Context," Journal of Marketing, 63(4), pp.38-56. 
Raju, S., H. R. Unnava, and N. V. Montgomery (2009), "The Effect of Brand Commitment on the Evaluation of Nonpreferred Brands: The Disconfirmation Process," Journal of Consumer Research, 35(1), pp.851-863.

Rusbult, C. (1980a), "Commitment and Satisfaction in Romantic Associations: A Test of the Investment Model," Journal of Experimental Social Psychology, 16, pp.172-516.

Rusbult, C. (1980b), "Satisfaction and Commitment in Friendships," Representative Research in Social Psychology, 11, pp.96-105.

清水 聰（2007）「プロモーション時の購買経験 が感情的コミットメントに与える影響」『流通 情報』、第 455 号、23-30 頁。

Steenkamp, J. E. M. and H. C. M. von Trijp (1991), "The Use of LISREL in Validating Marketing Constructs," International Journal of Marketing Research, 8(4), pp.283-299.

Sternberg, R. J. (1986), "A Triangular Theory of Love," Psychology Review, 93(2), pp.119-135.

Thibout, H. W. and H. H. Kelly (1959), The Social Psychology of Groups, John Wiley and Sons.

Traylor, M. B. (1981), Product Involvement and Brand Commitment, Journal of Advertising Research, 21(6), pp.51-56.

久保田進彦（2006）「リレーションシップ・コ ミットメント」『中京商学論叢』第 52 巻、 pp.47-180.

久保田進彦・井上淳子（2004）「消費者リレー ションシップにおけるコミットメントの多次 元性とその影響」『中京企業研究』第 26 号、 pp.11-27.

Warrington, P. and S. Shim (2000), “The
Empirical Investigation of the Relationship between Product Involvement and Brand Commitment," Psychology and Marketing, 17(9), pp.761-782.

山本晶（2005）「発信する顧客は優良顧客か？一 サイトの訪問動機とオンライン・ショップの購 買履歴データの分析一」『消費者行動研究』、第 11 巻 1,2 号、35-49 頁。

山本晶・阿部誠（2007）「消費者間ネットワーク を利用したレコメンデーション・エージェン 卜」、井上哲浩・日本マーケティング・サイエ ンス学会編著『Web マーケティングの科学』、 千倉書房、165-191 頁。

De Wulf, K., G. Odekerken-Schronder, and D. lancobucci (2001), "Investments in Consumer Relationships: A Cross-Country and CrossIndustry Exploration," Journal of Marketing, 65(4), pp.33-50.

〈注〉

1 組織コミットメント研究における Allen and Meyer(1991) が規定したコミットメント次元の うちの 1 つで、関係を解消することによるマ イナスの影響を回避することが主な動機とな るコミットメントである。

2 彼らは組織コミットメントを感情的コミット メント (affective commitment)、存続的コミッ トメント (continuance commitment) 規範的コ ミットメント (normative commitment) の 3 次 元で捉えている。

3 同研究については定性調査のみによって関係 の質的違いを導出している点で理論的基盤の 欠如が指摘されている（畑井 2004）。

4 調査は 1 回目が 2008 年 3 月 20 日から 4 月 28 日、2 回目が 2008 年 8 月 20 日から 9 月 18 日 に実施された。

5 Fullerton(2005)でも、本研究の計算的コミッ トメントに該当する存続的コミットメントか 
ら再購買意図への影響が 2 つの対象ブランド 中、一方しか認められなかった。また有意と なってもその係数は極めて小さいものであっ た。彼の研究と本研究の違いについて言及す
るならば、本研究では、計算的コミットメン トがバラエティ・シーキング行動を抑制し、 それにより特定ブランドの購買確率が高まる という間接的影響を解明できた点にある。 